\title{
Khondakar Ashraf Hossain's On Behula's Raft: An Exploration into Socio-Cultural, Political and Economic Aspects of Bangladesh
}

\author{
Liton Chakraborty Mithun \\ Department of English, University of Dhaka, Bangladesh \\ E-mail: litonchakrabortymithundueng@gmail.com
}

Doi:10.7575/aiac.alls.v.8n.2p.77

Received: 08/02/2017

URL: http://dx.doi.org/10.7575/aiac.alls.v.8n.2p.77

Accepted: 02/04/2017

\begin{abstract}
In the volume On Behula's Raft published in 2008 by Khondakar Ashraf Hossain, some significant social, cultural, political and historical aspects of Bangladesh figure repeatedly. This paper tries to explain how these aspects are reflected in Hossain's poems through text analysis of the primary material and some other primary and secondary sources. In this volume, Behula myth is found to be re-created and modified to suit Hossain's exploration into and celebration of, and commitment to Bangladesh, his beloved and beautiful motherland. Some important characters have been highlighted in this volume such as Bangabandhu's daughter Sheikh Hasina, a victim of fanaticism named Noorjahan, a legendary Bengali female poet called Kankabati and a Dhaka rickshaw-puller named Abushama to present various socio-politico-economic aspects of Bangladesh. Moreover, Bangladesh's liberation war, political reality, problems and potentials have been depicted in most of the poems in the volume. The paper implies that in On Behula's Raft, Hossain (2008) upholds a Bangladesh consciousness on an epical scale which has rendered great significance to the volume.
\end{abstract}

Keywords: Behula myth, Bangladesh, liberation war, political reality, victimization, patriotism, optimism

\section{Introduction}

The volume On Behula's Raft constituting of thirty-five poems published in the year 2008 is one of the most significant additions to Bangladeshi literature in English by Khondakar Ashraf Hossain, a leading contemporary Bangladeshi poet. It explores into the vivid landscape of the riverine country Bangladesh and her rich culture, myth and tradition. It also highlights the glorious liberation war of 1971, condemns anti-Bangladesh elements, and aspires to the resplendent future of the country. The Behula (1) myth which is exclusive to Bengal is intricately connected with Bangladesh's cultural identity. The poet promotes Behula as the very symbol of the country and reveals it in the foreword of the book thus: "Bangladesh is my Behula, on whose raft I have been afloat for eons- forever dying and resurrecting into new life under a resplendent tropical sun." (Hossain, 2008) He also re-creates and rearticulates the myth to capture and represent the evolution, changeover and development of social, political and cultural aspects of the country. Moreover, the quotidian life of the people, condition of Bengali women and the marginalized, various socio-political events of the country, and her exquisite natural beauty inform the creation of On Behula's Raft.

\section{Behula Myth Recreated to Symbolize Bangladesh}

In the title poem of On Behula's Raft, Hossain (2008) lends some extra dimensions to the Behula myth. In the original version, Behula is portrayed as the wife of Lakhindar. But in this poem, she also assumes a mother-like figure to him besides retaining her original identity as wife. Moreover, she is made to symbolize Bangladesh with all her social, political, cultural and historical experiences. In this connection, critic K. Rezaur Rahman observes:

Ashraf Hossain's poetry is suffused with his deep feeling for his motherland, its myths and legends, its political and social changes. The title poem does not offer any traditional interpretation of the Behula myth. On the contrary, Behula symbolizes the poet's motherland and the poem grows out of his patriotic zeal and national feeling for the land and its people. (2008)

In fact, the re-created Behula myth records and transcribes different aspects of Bangladesh.

\subsection{Lakhindar Symbolizing Bengalis}

The speaker identifies himself with Lakhindar and expresses his enragement toward Bangladesh in the form of Behula in the title poem "On Behula's Raft" as he shouts: "Why did you touch me, Behula, my Bangladesh?" (Hossain, 2008, p. 21). This dramatic opening brings into the spotlight the comfortable slumber similar to that of a mythic character from the Ramayana by Valmiki called Kumbhakarna who sleeps "constantly for six months at a time" (The Story of Kumbhakarna). The speaker has enjoyed, metaphorically, such a sleep on the raft. This sleep of the poet, the all-time Lakhindar, is evocative of the slumber of the Bengali nation at large under the poisonous effect of local and foreign 
forces. The speaker seems to imply that Bengalis have been lulled into a deep sleep of pitiable ignorance, dependence, stagnancy, and a baseless self-complacency. Lakhindar of today, the speaker is apparently, greatly annoyed as his Behula-Bangladesh has placed him in an encounter with darkness swirling in a vortex around the national life. The speaker says: "Waking, I saw darkness dissolve like water around the oar/and you holding my head in your palms/ amidst the ceaseless splash" (p. 21). It is possible that darkness here indicates to the local and foreign forces against the country's freedom, unbridled corruption, sluggish economic growth, population boom, political instability, uncontrolled crime etc. which have made the Bengali life turbulent and tumultuous.

\subsection{Lakhindar's as well as Bengali's Desired Awakening}

No nation can rise to glory and resolve the national crises without the active participation and movement of its members. Similarly, Bangladesh requires the rise of her citizens the way Behula needs Lakhindar to wake from poisoninduced slumber. It is implied in the title poem that the speaker and all other Lakhindars must stand upright for the national cause. Behula-Bangladesh appears to galvanize them into wakefulness. The speaker says:
At your touch my body now raises its cobra-like head;
In my veins the simmering heat of Jaishtha looks for dry grass
As though it would kindle an immense bushfire from a spark
Or, in momentary rage break a big chunk of from a boulder. (Hossain, 2008, p. 21)

Here, the "simmering heat of Jaishtha" perhaps stands for the potential of Lakhindar which can burn down the edifice of injustice, maltreatment, corruption and darkness weighing heavy on Bangladesh. He can pulverize "a big chunk of a boulder" which is symbolic of all difficulties and obstructions coming along Bangladesh's way to progress.

\subsection{Lakhindar alias Bengali's Inglorious Past}

Considering Lakhindar's portrayal in the last two sections of the paper, it seems that he has possessed a positive stance. He appears to be prepared to overcome all obstacles and historical failures facing Bangladesh. He, however, makes an honest confession regarding past failures and complicity. He says that he has enjoyed sadistically as well as masochistically the pains and sufferings of Bangladesh and her people. He further says that he has ignored "millions of Behula's outcries" (Hossain, 2008, p.21) and trundled down the demon of the "severed / heads of a million babies" (p. 21-22). His unacceptable response in the past betrays the crude reality of Bengali life that Bengalis have been emasculated across various phases of history. Another unbecoming issue about him is that "Draupadi's looted honor" (p.22) and "desperate moans" (p.22) have taken him to the "golden arbors of delight" (p.22). This sadistic attitude is a result of years of accumulated repression, the memory of which is lodged in the Bengali psyche. On top of that, to exacerbate the situation, the torturers are also seen to provoke him by showing him his "mother's image" (p.22). His reactions at these stages appear to be those of an impassive and a docile man, which implies the insensitiveness of many of the Bengalis toward their motherland.

\subsection{Behula as well as Draupadi Representing Bengali Women and Bangladesh}

Besides representing the motherland, Behula also represents Bengali women in general, suppressed and deprived of basic rights by their local and foreign male counterparts. It is notable that about 2-400000 lakh of Bengali women are raped by Pakistani army men and their Bengali collaborators during Bangladesh's liberation war of 1971(Roychowdhury, 2016). Besides these, Bengali women are allegedly dominated by men, and their sufferings know no bounds even still today. Again, Draupadi's case can be put under the lens of critical microscope. Draupadi is a mythic character of the Mahabharata by Vyasadeva and she is a common wife of the five Pandavas (Guin). The story goes that there is an enmity between the Kauravas and the Pandavas for the crown of the kingdom of Hastinapur. Kaurava prince Dusshasan attempts to strip Draupadi naked, at the command of Duryodhana, in front of her relatives including the Kauravas themselves, her five husbands and her in-laws. Her eldest husband Yudhisthir is hoodwinked into playing at and losing the game of chess since he is not good at it. After losing almost all his possessions, he has staked her in the gamble and lost her to the winning Kauravas. No sooner have they won her in the contest, they attempt to disrobe her in order to humiliate the Pandavas. Each and everyone seems to be a silent onlooker while she undergoes such humiliation since they are bound up with the shackle of so-called Dharma which is religious values and dutifulness of their own brand, and it is a woman who gets victimized by the man-manipulated Dharma (Warrier, 2011). In the poem "On Behula's Raft" Hossain (2008) probably implies that Draupadi is symbolic of his motherland Bangladesh, which has been molested and humiliated by many local and foreign forces across various phases of history. Thus, the poet perhaps attempts to present before his readers the image of sufferings Bengali women as well as Bangladesh as a country have experienced.

\subsection{Re-created Behula Myth Embodying Bengali’s Communal Divide and Genocide}

Another important historical reality Hossain (2008) brings forward is genocide and systematic ethnic cleansing of the Bengalis by successive colonial and semi-colonial regimes, like the British raj and Pakistani military-led government. Both the "Bengal Famine of 1770" and the "Bengal Famine of 1943-44" are creations of British policies (Maitra, 2015), the latter one being called "Bengali Holocaust" sponsored by Winston Churchill (Polya, 2011). In addition to that, mass killing of Bengalis to the tune of two-three million in 1971 is perpetrated by Pakistani junta in association with their local henchmen (Bangladesh Genocide Archive). The Pakistani junta then target Bengali Hindu minorities and call 
Bengali's freedom struggle a Hindu India's conspiracy, thus trying to confuse Bengali Muslim majorities in a bid to weaken the liberation movement. The same narrative is still pervasive as in the history textbooks taught in Pakistan ("Pak Textbooks"). However, the poet also highlights the destruction of both "temples and mosques" (Hossain, 2008, p. 22) - worship places of the Hindus and the Muslims respectively. This is perhaps evocative of communal riots between Hindus and Muslims sponsored by various opportunistic elements of society. Communal harmony between these two major religious communities have been severely disturbed leading to "the carnage [which] was especially intense, with massacres, arson, forced conversions, mass abductions, and savage sexual violence" (Dalrymple, 2015) before, during and after the partition of historical Bengal in 1947 along the religious-communal line powered by "two-nation theory" championed by Muhammad Ali Jinnah (General Knowledge Today, November 22, 2013). The shared cultural values, customs, literature and peaceful co-existence seem to have come under severe attack. Colonial powers, especially the British regime employ "Divide and Rule" policy in British India of which Bangladesh is a part (latasinha, 2012). The re-created Behula myth presented here sheds light on the assault on social, cultural and economic life of Bangladesh at different stages of her history.

\subsection{Behula-Bangladesh's Economic Exploitation}

On Behula's Raft spotlights economic exploitation of Bangladesh by both local and foreign forces. Hossain (2008) says: " ....you [have] borne me for so long from ghat to ghat/ seeking to revive me, resuscitate life in these parched limbs;/ You danced in Indra's divine court, you wept” (p. 22). Perhaps, Bangladesh's economic dependence on foreign aid and relief is indicated here. "The parched limbs" seems to signify the devastated and pitiable economic condition of Bangladesh and the Indian mythical god-king of Indra(2) perhaps represents the global economic powers and moneylending agencies. In addition to that, Behula's dancing "in Indra's divine court" (Hossain, 2008, p. 22) is perhaps an implication of Bangladesh's effort to appease foreign powers to garner economic aid. Moreover, the lines "laying me out naked on the sunlit pavement/ [You] begged for copper and dimes from foreign traders." (Hossain, 2008, p. 22) seem to corroborate Bangladesh's reliance on foreign corporate institutions and conglomerates for economic survival at a certain time. However, Bangladesh is exploited by some domestic forces who exploit their cunning and stratagem to serve their own economic interests and deprive most of the people. Hossain (2008) puts it metaphorically: "A shameless villain of the town lured you to deserted alley/ and stuffed handkerchief under your blouse” (p. 22). , Bangladesh has been economically exploited by foreigners including the British during 190 years of colonial rule (latasinha, 2012) and the Pakistanis between 1947 and 1971 as part of Pakistan (Samadder, 2009). In addition to that, he may indicate the corporate expoitation of Bangladeshis that renders them victims (Ismi, 2014). In fact, the poet reflects Bangladesh's economic situation through the adroit use of the re-created Behula myth.

\subsection{Lakhindar's Uprising Signaled}

The title poem "On Behula's Raft" signals to the rising conscious and forward-looking mindset of the awakened Lakhindar representing Bengalis. The speaker says, he is "struggling to be on my [his] feet again" (Hossain, 2008, p. 23). His confidence multiplies as his "chest [is] expanding" (p. 23) and ribs having "vanished under the muscles" (p. 23) He seems to realize that his purgation lies in two ways: he must take the responsibility for all the wrongdoings perpetrated against Bangladesh and admit his complicity for gross indifference to the motherland, and must settle the historical scores with a revisionist attitude. Therefore, he asserts that he must be "avenged for thousand deaths and denigrations" (p. 23). He also declares vengeance by taking "blood for blood, life for life" (p. 23). However, Bangladesh needs input and contribution from her beloved citizens who will sow "the seed of life" (p. 23) in every sphere. It transpires that he speaker is hopeful that "Spring-time cuckoo's calls" (p. 23) will be echoed all over heralding a new era in the national history. The speaker implies that through the concerted and synergistic effort of Bengalis walking "hand in hand" (p.23), the country will be "fruitful again with the immense stroke of light" (p. 23). The Bengali nation at large will "stand up against the ruthless sun" (p.23) of all kinds of oppression, suppression and domination. The title poem of On Behula's Raft, therefore, ends in a high-pitched note of optimism for overall enrichment and well-being of Bangladesh.

\section{Representation of Victimized Bengali Women}

Although positive and glorious representation of Bengali women is there in the text, the victimization of a section of them does not escape the poet's critical radar. Women's victimhood in the country both because of religious bigotry and superstitions outlined in the book is discussed down below.

\subsection{Victimization of Bengali Women by Bigotry}

The victimization of Bengali women receives an entry into Hossain(2008)'s On Behula's Raft. "Noorjahan" (Hossain, 2008 , p. 19) is one such representative poem that discusses the sad plight of Bangladeshi women at the hands of religious fanatics and zealots. It was written against the backdrop of a true incident occurred in Sylhet where a girl named Noorjahan was stoned to death by religious fanatics (Weaver, 1994). The poem starts with a smoldering sensation of hatred against the perpetrators of this heinous crime as the speaker asks an angry question. He says: "Water is boiling on the stove. / What's there inside the water?" (Hossain, 2008, p.19). The question recurs four times and receives each time a different but curious answer. The answers are respectively "Stones, only stones" (p. 19), "A woman's heart, her sari” (p. 19), “Only men, men's tongues" (p.19), “A whip lurks inside. And an ocean.” (p. 20). These images scrutinized carefully bear the implication that men's sadistic ego fed by fanatic ideologies can rip apart women- both physically and psychologically. Bangladeshi women till today languish in a suppressed and repressed situation and remain discriminated against and underprivileged (Islam, 2013). If Noorjahan is considered to be a 
symbolical microcosm of Bangladesh as a state, her destiny is vulnerable to be doomed by the fanatic and fundamentalist elements at the helm of political sphere, cultural domain and governmental power. It appears that the speaker refuses to yield to evil forces running rampant across Bangladesh and burning the nation under sweltering heat of fundamentalists-sponsored medieval agenda. That is why, perhaps, the speaker mythicizes Noorjahan to accommodate her sacrifice in the grand narrative of Bangladesh's socio-politico-cultural resistance against bigotry, fanaticism, religiosity and fundamentalism. Unlike Philomela in Greek myth who is metamorphosed into a nightingale singing sweet songs after suffering sexual assault from her brother-in-law King Tereus (Barnett et al., 2017), Noorjahan will be transformed into the attacking bird of Ababeel referred to in the Koran who attacked an elephant convoy with a heavily-equipped army, directed to Mecca by King Abraha of Yemen with a view to destroying it (Quranic Story). While T.S Eliot (1920) uses Philomela's transformation into a song bird as a symbol of beauty out of violence in the poem titled "Sweeney Among the Nightingale", Hossain (2008) presents Noorjahan's imaginative transformation as in the eponymous poem as a symbol of violence against all such crimes against humanity in general and women in particular.

\subsection{Victimization of Women by Superstition}

Hossain (2008)'s On Behula's Raft focuses also on Bengali women and their multi-dimensional victimization. As discussed already, Bengali women have been victims of male hegemony and superstitious behavior. His poem "Woman and Witchdoctor" records such an incident where a snake-bitten female patient undergoes the superstitious and baseless faith healing process that deteriorates her condition pushing her gradually to the mouth of death (Hossain, 2008, p. 63). Interestingly, the healer uses rituals of both Hindus and Muslims respectively as the charmer chants both "one hundred and eight names of lord Krishna" (p. 63) and the "holy Isme Azam" (p. 63). This testifies to the fact that both the major communities of Bangladesh living, especially in the villages still maintain a miserable existence ridden with superstitions. Invariably, women mostly become victims to these kinds of medieval practices and further marginalization. Professor Rebecca Haque has observed:

The poem is the poet's strong indictment of superstition, ignorance, and bigotry, which have for generations kept the women of rural Bengal physically bound in space and spiritually confined in imaginative sterility, without scope for expression of autonomous voice in work or place. (2013)

Therefore, Hossain (2008) is successful in promoting Bengali women's cause through this very poem.

\section{Politics of Bangladesh}

Hossain's On Behula's Raft (2008) is marked by political views and ideas. The speaker appears to be a follower of a progressive political ideology. A pro-liberation spirit, an admiration for democracy and a criticism of anti-Bangladesh elements seem to characterize the volume. Political aspects of the book are discussed below.

\subsection{Admiration for Sheikh Hasina and Liberation War}

Sheikh Hasina, the daughter of the founder as well as father of the nation of Bangladesh Bangabandhu Sheikh Mujibur Rahman, and the three-time premier of the country is a significant presence in On Behula's Raft (Hossain, 2008). The poem titled "Poem for Sheikh Hasina" (Hossain, 2008, p. 14) is a scintillating example where, similar to the poems discussed earlier, Sheikh Hasina also seems to attain a symbolical dignity as the embodiment of all aspiration and hope of Bangladeshi people. In this poem, the speaker perhaps compares the anti-Bangladesh conspirators engaged in the plot of killing Sheikh Hasina and her comrades and also in destroying the spirit of liberation war with the "thunder-stricken palm-tree" (Hossain, 2008, p. 14) that cannot provide the "dictionary of green" (p.14). The speaker also compares them with "the black bat" (p.14) unable to understand "the meaning of deep night (p.14), with the "red ants" (p. 14) unaware of "the whereabouts of the sun" (p. 14) and with the crude killer ignorant of the "color and combination of hemoglobin." (p. 14). His dismissal of such crooked plotters is strongly manifested when he points to some crisis period of national life which is doctored by "the grammar of the absurd" (p. 14). He also equates that bad patch with the "long-robed darkness" (p. 14) which "threatens the courtyard of light" (p. 14). Moreover, his enragement at the cowardice of the evil force nestled in power is laid bare in the following parenthetical lines: "(when the horsemen are away the toads of the plains/ clamor to win gold medals in hundred meter sprints.)" (p. 14). Moreover, the poet depicts the anarchical situation and misrule facing the country through some evocative images and invites strong nullification of them on the part of the readers. He says,

$$
\begin{aligned}
& \text { The spiral bangles on mother's hands unwind; } \\
& \text { Patience and sari's end burst their bounds; } \\
& \text { King's talons scoop out our eyes to make us blind; } \\
& \text { Our rages burst like the heated bean-pods. (p. 14) }
\end{aligned}
$$

Against this murky juncture of national history, the speaker requests Sheikh Hasina to be well-prepared for all future dangers with these words: "Keep up your ammunition for the coming winter" (p. 14). He also enunciates his belief that only she can "cover the bite-marks" (p. 14) of Bangladeshi's collective "memories under the enchanted sleep of a black tapestry" (p. 14). In addition to that, the speaker seems to be upset with the status quo of this country and probably, he needs some psychological relief. He implies that only she can give him and his compatriots consolation and hope for a 
hunger and poverty-free happy Bangladesh in the lines "We know once you told us the story of sleepless joy,/ the fairytale of the koi fish creeping/ towards the starving men's plate."(p. 14). This poem perhaps indicates the development of "1/11" in the year 2007 during which "minus-two formula" is employed by the military-backed, so-called Care-Taker Government to remove Sheikh Hasina among others from Bangladesh's political scene (Mahmud, 2016). It is alleged that democratic values experiences a nosedive, and constitutional rules and regulations are compromised under the veneer of political reform in that period. Nevertheless, the speaker appears to refuse to lose hope and chooses to be patient. He concludes, "It's better for the flower and the blood to take rest now. / Meanwhile let the toads of the plains dance their Bharatnatyam" (p. 15). In fact, the poem highlights Sheikh Hasina's importance as the leader of Bangladesh.

\subsection{Pro-Liberation Spirit}

In Hossain's On Behula's Raft (2008) seems to champion a political ideology which is very much fashioned along the spirit of Bangladesh's war of liberation. In an attempt to criticize Bengalis of their negligence toward the glorious history of independence struggle and liberation war, the speaker invokes Kankabati (3), an "epitome of Bangla womanhood" (Haque, 2013) in the post-liberation war Bangladesh and recognizes her as a witness of the liberation struggle and the subsequent losses Bangladesh has made. The poem titled "From the Mass-Graves" (Hossain, 2008, p. 34) records the sacrifices made by Bangladesh, and Kankabati is invoked to witness how the successive generations seem to be oblivious of them. In this connection, Prof. Soumitra Sekhar's evaluation in Bangla can be taken into account. To put it into English:

He [Ashraf Hossain] did not just experience the face-to-face battle; he also connected his consciousness and sense of tradition to it. That is why, Ashraf Hossain accepted a folk-tale heroine [Kankabati] as the witness to his remembrance of martyred men and women; also in the memory war-heroines who lost their honor. When bone-heaps of the martyrs are discovered, it becomes difficult for him to hold back tears. (Sekhar, 2014, p. 109)

In a cathartic manner, the speaker invokes her to share his grief. He cries, "Kankabati, come and see/ Your beloved Bangladesh." (Hossain, 2008, p. 34). The amount of pains and pangs he implies to have suffered is unfathomable since most of his compatriots appear to be oblivious of how large a price Bangladesh has paid to earn freedom. To condemn this forgetful tendency of Bangladeshis to the liberation war, another poet Akhtaruzzaman Azad similarly terms many Bangladeshis born in the eighties and nineties as the "Selfish Goldfish" (Azad, 2012, p. 10) in the poem "Goldfish Available Here" , because the goldfish is popularly believed to have the shortest possible memory of all creatures (Soniak, 2010). The speaker further laments: "The plaster of our forgetfulness now covers/ Their lipless rows of teeth." (Hossain, 2008, p. 34). However, Bangladesh's soil is still "blood-red" (p. 35) as three million people have sacrificed their lives. Furthermore, their mortal remains are found in multiple killing grounds which have turned Bangladesh into "a goldmine of bones." (p. 34). The speaker, therefore, implies that the martyrs mock at Bengalis' denial mood and forgetful negligence to their sacrifice. Hossain (2008) puts this thus:

Those Yorics- whom you call

By the name of shaheed-

They only laugh at our folly

The million skulls laugh out in chorus (p. 34)

In fact, the collective failure of successive generations in living up to the spirit of the liberation war is an unpardonable offence. By portraying the martyrs as laughing at the folly of the nations, the poet poignantly denounces the darker side of the Bengali nation as exposed at various points of history.

\subsection{Bengali's Love for Democracy}

Ashraf Hossain is a politically conscious poet and his On Behula's Raft (Hossain, 2008) reflects the poet's as well as Bengalis' admiration and love for democracy and their participation in democratic movements. Therefore, the poet's "special sensitivity toward any conspiracy against and adulteration of the history and tradition of Bangladesh perpetrated by anti-Bangladesh forces" (Mehdy, 2014, p.145) perhaps prompts him to write pro-democracy and secularly motivated political poems. For example, “About Green” is a politically evocative poem which places especial emphasis on the year 1988 (Hossain, 2008, p. 28). This year is politically significant year in Bangladesh's history. The incumbent military ruler H. M. Ershad declares Islam as the state religion of the Muslim-majority nation, allegedly in a bid to "seek mass support during a campaign by major political parties to oust him from power." (Hussain, 2016).The controversial fourth general election is held under him where his party entrenched its power amid widespread allegations of vote-rigging, election-engineering, coercion along with killings in both pre- and post-election violence (Tefft, 1988). The speaker of the poem "About Green" perhaps implies to negate his party hooligans and military people as thugs and fraudsters who are crucial to helping Ershad to remain in the comforts of power betraying with the people of the country (Hossain, 2008, p. 28). He also seems to nullify them as the hostile elements opposed to the spirit of country vivid with her green landscape. He says: "1988, the year on the almanac, / is for those who hate green." (p. 
28). He perhaps labels negatively the president's sycophants as the "hired menials" who are "digging the horizons to put up a stable". (p. 28). Therefore, the speaker implies that the forceful occupation of the state power by Ershad and his cohorts is tantamount to putting up a stable, hence the denigration of undemocratic and autocratic rule and the ruler. Moreover, the deception and cheating on the part of the then political goons is dismissed by the speaker as the camouflage by a green "laudugi snake" (p. 28) which also evokes the biblical serpentine imagery. In this manner, the speaker as well as the poet seems to relegate military or autocratic takeover of Bangladesh into a satanic enterprise. In addition to that, the decision to constitutionalize the state religion perhaps appears to him as a case of "myopia" which the Bangladesh's favorite color "green does cure” (p. 28). Thus, the poem reflects Bangladesh's political issues in a vivid manner.

\section{Representation of the Marginalised}

The volume On Behula's Raft represents the marginalized people of the land. Already the marginalization of Bengali women has been discussed above. However, this text is also sympathetic and affectionate toward the marginalized working class people living at the bottom of socio-economic rung. That is why, a rickshaw-puller named Abushama enjoys a respectful place in the poem "Abushama's Horse" (Hossain, 2008, p. 31-32). To quote a stanza: "Twelve battles were fought by Alexander the Great; / The thirteenth he fought at Tongi Town gate" (p. 31). The speaker metaphorically compares Alexander the Great with the poor Rickshaw-puller Anushama by terming him the "black prince of ours" fighting "his battles at Tongi Town gate" (p. 31). Besides him, poor and simple people of rural Bengal including Naber, Samed Munshi, Samed Munshi's daughter, Dulu, Dulu's wife find their way into the poem "A Fourfooted Epiphany" (Hossain, 2008, p. 36). In fact, "incidents and situations from common life" with a "certain coloring of imagination" (Wordsworth, 1800, p. 5) informs these poems.

\section{Celebration of Bangladesh's Natural Beauty}

Hossain's On Behula's Raft (2008) also eulogizes the natural beauty of Bangladesh. There are a few poems where Bangladesh's green landscape, rural scenery and Bengali women assume a romanticized place. In "About Green", he eulogizes the greenness of Bangladesh by saying-

My country has the fame of being green,

Women look killing in the green saris. (Hossain, 2008, p. 28)

In another poem titled "The Inter-city Train", the speaker appears to imagine Bengali's best poet Rabindranath Tagore in the vivid landscape of Bangladesh (the then Eastern Bengal) to imply that it nourishes Tagore's creative faculty (Hossain, 2008, p. 25). The "Chaitra jute-field" (p. 25) is a common feature of rural Bengal, and jute is considered the "golden fibre of Bangladesh" (Help Desk) for its economic importance. The strongly built Bengali peasant's nifty hand becomes a "relentless hound looking for weeds among eight-inch plants" (Hossain, 2008, p. 25). This delineates the struggle of the Bengali peasants which they undergo on daily basis throughout the year. The speaker perhaps out of a euphoric sensation at the sight of this scene experiences a mental journey by the "train of the heart" (p. 25). The borderline between reality and imagination seems to blur away for the speaker. He stops and peers into the water, "where Rabindranath has cast anchor to watch the fishes splash" (p. 25). The ethereal beauty of rural landscape probably casts a psychedelic effect on him as it does on Tagore. The "dark village belle", the "bathing wife" as well as her husband popping up his head "from the jute-field" would look curiously at the poet Tagore "inside the boat writing letters to his far-off niece” (p. 25). The imagery of riparian Bangladesh would stimulate and inform Tagore's creativity and so it does to the speaker. Another poem titled "Tango" also celebrates the beauty of rural Bangladesh (Hossain, 2008, p. 58). The speaker eulogizes rural nature of Bangladesh thus:

The cloud figure-skates
on the swaying aman sheaves.
Touching the boats' prow
on the dark waters of the beel
the turbulent cloud hoofs up a flamenco swirl
long hair/ floating in a frenzied glee." (Hossain, 2008, p. 58)

In this regard, critic K. Rezaur Rahman says,

Hossain has written many pure lyrics, some of them based on the natural scenery of Bangladesh. His evocation of the visual scene of the playful wind and rain on the vast paddy fields is spellbinding. (2008)

In short, the poems celebrate the scenic beauty of rural Bangladesh. 


\section{Conclusion}

What is sui generis about Khondakar Ashraf Hossain is that he has quite the cachet of a committed patriotic Bengali poet. The poetic exploration and re-creation of Bangladesh being Hossain's bailiwick, his poetry internalizes Bangladesh as its vital force. Thus the volume On Behulas Raft records his views of, reflection on and response towards several important aspects concerning Bangladesh in its multiplicity. The study has explored several poems of the volume and identified significant social, cultural, political and historical aspects of the country that has been represented through metaphors and symbols. The paper, dealing with how these aspects have been presented in the volume clearly implies and establishes the significance of On Behula's Raft as an important document where Hossain (2008) upholds Bangladeshi consciousness on epical scale. The words in the blurb of his chef-doeuvre On Behulas Raft encapsulate it all: "Ashraf Hossain's poetry is deeply concerned with the celebration of his motherland, its myths and metonymies, its political and social exigencies." The paper is a critical intervention to unearth these aspects.

\section{References}

Azad, A. (2012), "Ekhaney Sonamachh Pawa Jay” (Goldfish Available Here), Samarik Kabi, Besamarik Premik (Military Poet, Civil Lover), Basbhumi Prakashani, P. 10.

Bangladesh Genocide Archive, [Web]. Available at http://www.genocidebangladesh.org/

Barnett et al. (2017), "Philomela and Ovid", Ovid and the Censored Voice [Web]. Available at

http://web.colby.edu/ovid-censorship/censorship-in-ovids-myths/philomela-ovid-silencing-censorship/

Dalrymple, W. (June 29, 2010), “The Great Divide: The violent legacy of Indian Partition.” The New Yorker. Retrieved from http://www.newyorker.com/magazine/2015/06/29/the-great-divide-books-dalrymple

Eliot, T. S. (1920), "Sweeny among the Nightingales”, Poems. Available at http://www.bartleby.com/199/24.html

Guin, M., "Draupadi, the Woman: Epitome of Feminity and Feminism”, Dolls of India, [Blog]. Retrieved from

http://www.dollsofindia.com/library/draupadi/

Haque, R. (2013, June 22), On Behula's Raft - Allure of Myth and Metaphor. The Daily Star. Retrieved from http://www.thedailystar.net/news/on-behulas-raft-allure-of-myth-and-metaphor

Hossain, K. A. (2008), On Behula's Raft. Dhaka: Writers.ink.

Hussain, M. (Mar 28, 2016), "Keeping Islam as State Religion in Bangladesh Triggers Mixed Reactions", VOA. Retrieved from http://www.voanews.com/a/bangladesh-islam-state-religion/3258149.html

Islam, S. (July 9, 2013), "Women’s rights and discrimination in Bangladesh”, The Dhaka Tribune. Retrieved from http://archive.dhakatribune.com/op-ed/2013/jul/09/women\%E2\%80\%99s-rights-and-discrimination-bangladesh

Ismi, A. (Feb 1, 2014), "Bangladeshis Victims of Corporate Exploitation", Canadian Centre for Policy Alternatives (CCPA), [Web]. Available at

https://www.policyalternatives.ca/publications/monitor/bangladeshis-victims-corporate-exploitation

latasinha (July 15, 2015), "Divide and rule policy" in India before and after the independence”, Latasinha's Weblog. [Web]. Available at https://latasinha.wordpress.com/2012/07/15/2479/

Mahmud, A. H. (Updated: Mar 6, 2016), “Quader: More study needed on 1/11”, The Dhaka Tribune. Retrieved from http://archive.dhakatribune.com/politics/2016/mar/05/quader-more-study-needs-know-111

Mehedy, M. (2014), “Yugapat Pathaker Mon O Chetonar Porshi”(Neighbor to Reader's Both Mind and Consciousness). Nisarga, 29(01), 142-150

"Pak textbooks focus on conspiracy theories on 1971 war", (Dec 16, 2010), The Times of India World. Retrieved from http://timesofindia.indiatimes.com/world/pakistan/Pak-textbooks-focus-on-conspiracy-theories-on-1971war/articleshow/7111377.cms

Polya, G. (June 13, 2011), "WW2 Bengali Holocaust: "Churchill's Secret War" By Madhusree Mukerjee", Countercurrents.org, [Web]. Retrieved from http://www.countercurrents.org/polya130611.htm

Rahman, K. R. (Mar 29, 2008), “A poetic soul nourished by poetry”, The Daily Star. Retrieved from http://www.thedailystar.net/news-detail-29688

Roychowdhury, A. (Dec19, 2016), "Birth of Bangladesh: When raped women and war babies paid the price of a new nation", The Indian Express. Retrieved from

http://indianexpress.com/article/research/birth-of-bangladesh-when-raped-women-and-war-babies-paid-the-price-of-anew-nation-victory-day-4430420/

Samadder, R. (Sep 16, 2009), "Bangladesh, Exploitation of East by the West”, Marxist, [Web]. Available at

http://radhikaranjanmarxist.blogspot.com/2009/09/bangladesh-economic-exploitation-by.html 
Soniak, M. (May 24, 2010), “Do Fish Really Have a Three-Second Memory?”, mental_floss [Web]. Retrieved from

http://mentalfloss.com/article/24763/do-fish-really-have-three-second-memory

“The Golden Fiber of Bangladesh (Jute)", (Nov 29, 2011), Top Information Help Desk [Blog]. Available at

http://topinfodesk.blogspot.com/2011/11/golden-fiber-of-bangladeshjute.html

"The People of Elephant \& the Army of Ababeel (Quranic Story)", Musjidul Haq [Web]. Available at

https://musjidulhaq.com/2016/03/08/people-of-elephant-the-army-of-ababeel-quranic-story

"The Story of Kumbhakarna", Kriya Yugah, [blog]. Available at http://kriyayogagurupranam.blogspot.com/p/story-ofkumbhakarna.html

Warrier, A. (Sep 01, 2011), "Mahabharata/Jaya - Draupadi Vastraharan (Disrobing)”, Road of Life, [Blog]. Retrieved from http:/greatlittlewarrior.blogspot.com/

Weaver, A. M. (Sep 12, 1994), “A Fugitive from Injustice”, Letter from Bangladesh, The New Yorker. Available at http://www.newyorker.com/magazine/1994/09/12/a-fugitive-from-injustice

Wordsworth, W. (1800), "Preface to Lyrical Ballads", Bartleby.com [Web]. Retrieved from http://www.bartleby.com/39/36.html 